\title{
RELATION OF BENTHIC MACROINVERTEBRATE COMMUNITY IMPAIRMENT TO BASIN CHARACTERISTICS IN NEW JERSEY STREAMS
}

The U.S. Geological Survey's (USGS) National Water Quality Assessment (NAWQA) Program was implemented in 1991 to address the need for a consistent description of the Nation's water resources. The NAWQA Program is organized into 59 study units that encompass many of the Nation's major river and aquifer systems. Work in the 6,000square-mile Long Island-New Jersey (LINJ) study unit, which includes some of the most heavily urbanized and populated areas in the United States, began in 1994.

One of the primary goals of the NAWQA Program is to identify and evaluate the physical, chemical, and biological factors that affect aquatic communities. This evaluation typically is accomplished through (1) analysis of available data and (2) intensive assessments of water chemistry and aquatic communities within each study unit. The present study is an examination of data on more than 700 samples of benthic macroinvertebrates collected as part of the New Jersey Department of Environmental Protection's (NJDEP) Ambient Biomonitoring Network (AMNET) program during 1992 to 1996 (fig. 1).

In the past, the integration of biological and water-quality data on a watershed or larger scale has been hindered by the lack of consistent data, the small number of sites for which both types of data were available, and the high cost of simultaneously collecting a comprehensive suite of biological and water-quality data. The introduction of Rapid-Bioassessment Protocols (RBP's; see the Methods and Analytical Approach section for a description) by Karr (1981) and Plafkin and others (1989) has provided State and local agencies with a cost-effective framework for assessing biological communities. A need still
The New Jersey Department of Environmental Protection's Ambient Biomonitoring Network (AMNET) is a statewide network of macroinvertebrate sampling sites that incorporates regional reference sites. Regional reference sites are minimally disturbed areas organized by selected chemical. physical and biological characteristics (New Jersey Department of Environmental Protection, 1994; Reynoldson and others, 1997). The goal of the program is to monitor the condition of benthic macroinvertebrate communities on a 5-year rotational basis. This sampling frequency is considered to be a realistic time lag for evaluating longterm environmental changes. Sampling locations were chosen for monitoring mainstem locations above major tributary confluences, assessing the effects of lakes, investigating known sources of contamination, and evaluating the effects of significant natural features such as wetlands, preserves, and wildlifemanagement areas (fig. 1). In addition. this network was designed to incorporate, wherever possible, existing USGS and NIDEP cooperative water-qualitymonitoring stations to maximize the integration of water-quality and biological information.

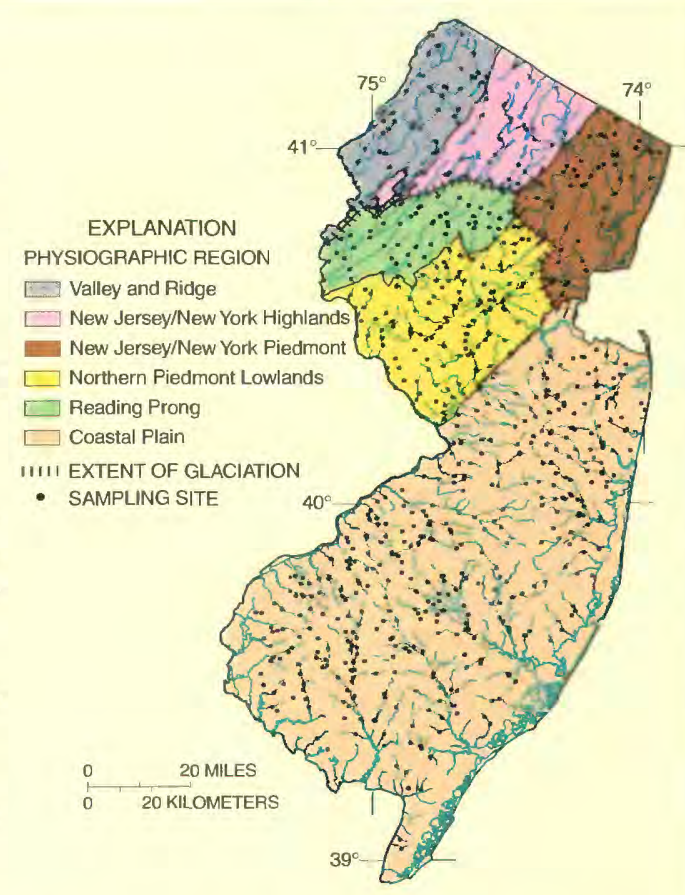

Figure 1. Location of New Jersey Department of Environmental Protection's Ambient Biomonitoring Network sampling sites, physiographic regions, and extent of glaciation in New Jersey.

\section{Important Findings}

In this study, the level of macroinvertebrate community impairment at more than 700 stream sites in New Jersey was examined with respect to physiographic region, major drainage area, and selected basin characteristics. Relevant findings are as follows:

- Impaired macroinvertebrate communities were most likely to be found in the New Jersey/New York Piedmont, Northern Piedmont Lowlands, and Coastal Plain physiographic regions.

- The fewest severely impaired sites were found in the Reading Prong and the Valley and Ridge physiographic regions.

- Impaired macroinvertebrate communities were least likely to be found in the Upper Delaware River drainage area.

- The best predictor of the presence of an unimpaired benthic community was the total area of forested land located upstream from a sampling site.

- The best indicators of the presence of a severely impaired benthic community was the total area of urban land in close proximity to a sampling site and total flow of municipal wastewater effluent. 
exists, however, to relate water-quality information to measures of biological condition derived from rapid bioassessments, and to examine the sensitivity of these conditions at the basin and state scales. These types of assessments are becoming increasingly important as State and Federal agencies continue to identify problems associated with point- and nonpoint-source contamination, to integrate multiple lines of evidence into waterquality assessments, to document long-term regional changes in water quality, and to supplement statewide water-quality inventory reports (Section 305(b) of the Federal Clean Water Act).

This fact sheet evaluates differences in macroinvertebrate community impairment among major drainage areas and physiographic regions in New Jersey, and relates macroinvertebrate community impairment ratings derived by using a modified rapid-bioassessment approach to selected basin characteristics of New Jersey streams. These results will aid surface-water managers in the design of future biomonitoring efforts and in the identification of (1) minimally disturbed systems that are at risk for future degradation, (2) possible factors affecting the health of New Jersey streams, and (3) regions of New Jersey where concerted remediation efforts would be most effective.

\section{Methods and Analytical Approach}

A rapid-bioassessment method for identifying and evaluating regional differences in the health of benthic macroinvertebrate communities was developed and field-tested in New Jersey streams. This method was modified from the U.S. Environmental Protection Agency's Rapid Bioassessment Protocol II (Plafkin and others, 1989). Rapid bioassessments are based on a multimetric approach - that is, an approach that uses an array of individual measures (community, population, and functional) to summarize diverse biological information into a single measure of biological condition. Individual measures of biological condition (referred to as metrics) for each sampling site are compared to a composite New Jersey-wide reference data base (New Jersey Department of Environmental Protection, 1994). On the basis of this comparison, a total community "impairment score" is established that is adjusted for regional

Table 1. Land use and population density in major physiographic regions of New Jersey

[Population data from U.S. Bureau of the Census (1991); Anderson level I land-use data from Fegeas and others (1983). CP. Coastal Plain: RP, Reading Prong; NH, New Jersey/New York Highlands; PL, Northern Piedmont Lowlands; PD, New Jersey/New York Piedmont; VR, Valley and Ridge; <, less than]

\begin{tabular}{|l|c|c|c|c|c|c|}
\hline \multirow{2}{*}{$\begin{array}{l}\text { Land-use } \\
\text { category }\end{array}$} & \multicolumn{6}{|c|}{ Land use (in percent of physiographic region) } \\
\cline { 2 - 7 } & $\mathrm{CP}$ & $\mathrm{RP}$ & $\mathrm{NH}$ & $\mathrm{PL}$ & $\mathrm{PD}$ & VR \\
\hline Urban & 18 & 14 & 16 & 25 & 78 & 4 \\
\hline Agricultural & 24 & 33 & 8 & 48 & 1 & 45 \\
\hline Forest & 35 & 51 & 69 & 23 & 11 & 46 \\
\hline Water & 4 & $<1$ & 5 & 2 & 4 & 2 \\
\hline Wetland & 16 & $<1$ & $<1$ & 2 & 4 & 2 \\
\hline Barren & 2 & $<1$ & 1 & $<1$ & 2 & 1 \\
\hline \multicolumn{7}{|c|}{ Average population density } \\
\hline People per acre & 1.0 & 0.8 & 0.8 & 1.4 & 7.1 & 0.2 \\
\hline
\end{tabular}

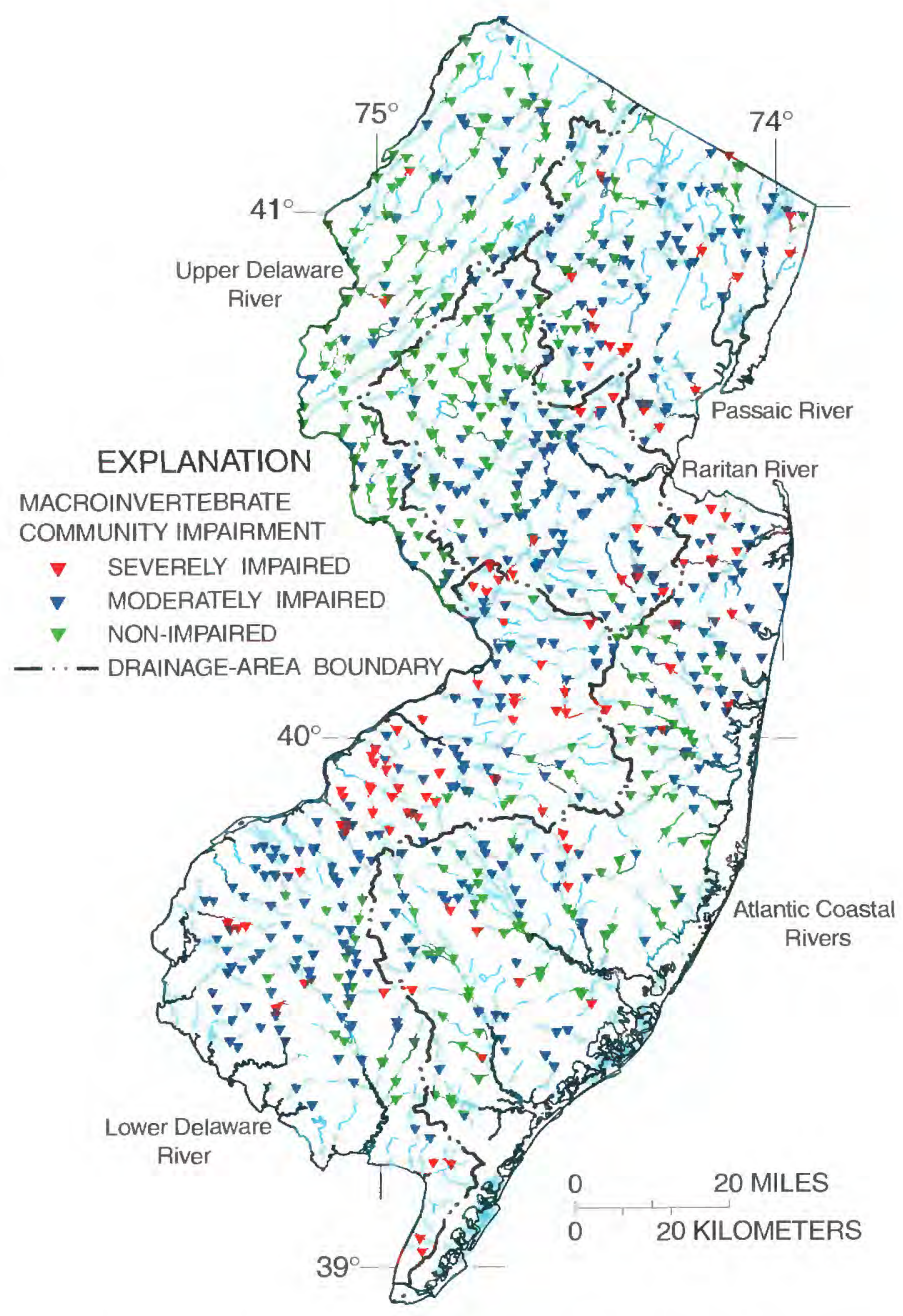

Figure 2. Levels of community impairment at New Jersey Department of Environmental Protection's Ambient Biomonitoring Network macroinvertebrate sampling sites in major drainage areas of New Jersey.

differences in macroinvertebrate-community composition. Benthic macroinvertebrates are ideally suited for this type of approach because they are sensitive to minor changes in water quality and, therefore, are useful as indicators of a wide range of environmental disturbances.

Benthic-macroinvertebrate samples were collected from 1992 to 1996 , during stable-flow periods, from sites within stream reaches containing representative geomorphic units (riffles, runs, and pools). To maintain consistency among sampling sites, a qualitative multihabitat sampling design (see Cuffney and others, 1993) that integrates productive and stable areas of similar substrate composition (cobble-riffle/run, snag, banks, and depositional areas), stream velocity, water depth, and vegetation cover was applied. Benthic macroinvertebrates were typically sampled with a Surber sampler or a rectangular kick net (500-micrometer mesh) in fast velocity riffle/run sections of the stream channel. A grab sampler was used to collect benthic macroinvertebrates located in depositional areas. In addition, a separate sample of coarse particulate organic matter (primarily decomposing leaf litter) was collected by hand. All material from the samples was composited and preserved. Samples were later sorted and all macroinvertebrates were identified and counted. A family-level 100-organism subsample was randomly generated from the entire sample. Three condition categories 
(non-impaired, moderately impaired, and severely impaired) were established to reflect the type and level of macroinvertebrate-community impairment in New Jersey streams (refer to table 3 for a description of impairment level and range of scores).

Analysis of variance was used to statistically evaluate differences in mean level of impairment among all six physiographic regions and five major drainage areas (Helsel and Hirsch, 1992, chap. 7). If the mean level of impairment was found to differ among regions or basins, then a multiple comparison test (Tukey test; Zar, 1984, p. 186-190) was performed to determine which mean impairment score(s) differed. For this analysis, two northern physiographic provinces were subdivided into glacial and nonglacial regions (fig. 1). Also, because land use and thus population density varies within the physiographic regions, data for each of five major drainage areas (fig. 2) were aggregated to represent the types and degrees of development in New Jersey and to maintain consistency with drainage areas used in the AMNET program. Land-use and population information for the six physiographic regions and five major drainage areas is summarized in tables 1 and 2 , respectively. All statistical tests for these comparisons were performed at the 95-percent confidence level $(\alpha=0.05)$.

Logistic-regression analysis (a non-linear regression approach) of basin characteristics was used to develop equations that defined the likelihood of macroinvertebrate community impairment above the three established levels (table 3). (Refer to Hosmer and Lemeshow (1989) for additional information on logistic-regression analysis.) Basin characteristics considered in this analysis include total flow from point source of contamination, total municipal wastewater effluent, biochemical oxygen demand, land use, population, and physiographic region. Total area occupied by urban, forested, and agricultural land, total population, and total area within each physiographic region were obtained by using a distance-weighted and spatially distributed model of more than 7,200 stream reaches. (White and others (1992) provide additional information about this model.) Land-use categories used in the model were based on classification of Landsat Thematic Mapper data (data derived from satellite-based observations of the Earth's surface) for August 1985 and level I Anderson classifications of 1:250,000 land-use data compiled from high-altitude aerial photographs

Table 2. Land use and population density in major drainage areas of New Jersey

[Population data from U.S. Bureau of the Census (1991); Anderson level I land-use data from Fegeas and others (1983). ACR, Atlantic Coastal Rivers; LDR, Lower Delaware River; PAS, Passaic River; RAR, Raritan River; UDR, Upper Delaware River; <, less than]

\begin{tabular}{|l|c|c|c|c|c|}
\hline \multirow{2}{*}{$\begin{array}{l}\text { Land-use } \\
\text { category }\end{array}$} & \multicolumn{5}{c|}{ Land use (in percent of drainage area) } \\
\cline { 2 - 7 } & ACR & LDR & PAS & RAR & UDR \\
\hline Urban & 17 & 21 & 48 & 26 & 13 \\
\hline Agricultural & 7 & 28 & 3 & 40 & 25 \\
\hline Forest & 47 & 35 & 41 & 30 & 55 \\
\hline Water & 9 & 3 & 3 & 1 & 3 \\
\hline Wetland & 18 & 11 & 4 & 2 & 3 \\
\hline Barren & 2 & 1 & 1 & 1 & $<1$ \\
\hline \multicolumn{7}{|c|}{ Average population density } \\
\hline People per acre & 1.0 & 0.3 & 4.2 & 1.7 & 0.2 \\
\hline
\end{tabular}

(Anderson and others, 1976). Population estimates were obtained from the 1980 Census of Population and Housing (Lanfear, 1993).

\section{Do Physiographic and Drainage-Area Characteristics Affect Levels of Benthic Macroinvertebrate Community Impairment?}

Levels of benthic macroinvertebrate community impairment in the six physiographic regions and five major drainage areas were compared. Results of this comparison indicate that the levels of impairment are not equal. Results of the multiple comparison test indicate that the level of impairment in the New Jersey/New York Piedmont and Northern Piedmont Lowlands did not differ significantly from that in the Coastal Plain (fig. 3). These three physiographic regions were most likely to exhibit an impaired macroinvertebrate community. Impairment levels were not significantly different in the Reading Prong and the Valley and Ridge physiographic regions, where the frequency of impaired macroinvertebrate communities was lowest.

Results of comparison of benthic macroinvertebrate community impairment among major drainage areas (fig. 3) indicate that the mean impairment rating in the Upper Delaware River drainage area was significantly different from those in all the other drainage areas and that the Upper Delaware River drainage area was least likely to exhibit an impaired community. The level of impairment in the Atlantic Coastal Rivers drainage area did not differ significantly from that in the Raritan River drainage area; it did differ significantly, however, from levels of impairment in the Lower Delaware and Passaic River drainage areas (fig. 3), which were most likely to exhibit an impaired macroinvertebrate community.

\section{Which Basin Characteristics Most Affect Benthic Macroinvertebrate Community Impairment?}

Levels of benthic macroinvertebrate community impairment established by the NJDEP (non-impaired, moderately impaired, and severely impaired) were calculated for more than 700 sampling sites throughout New Jersey (fig. 2). Impairment ratings were then related to basin characteristics (explanatory variables) specific to each sampling site by using logisticregression analysis. Five basin characteristics were found to be highly related to the level of community impairment. Those basin characteristics that best describe community impairment were the area of land near the sampling site classified as either urban (URB-3) or forested (FOR-3); area within the Reading Prong (RP-3) and Coastal Plain (CP-3) physiographic regions; and total flow of municipal wastewater effluent (PFM-5) (table 3).

In this analysis, the best-fit logistic regression equation indicated that the likelihood of detecting a severely impaired benthic macroinvertebrate community was negatively related to the total area of forested and undeveloped land and to the total underlying area in the Reading Prong physiographic region, and positively related to the area of urban land upstream from a sampling site. If physiographic variables are not considered, the best-fit equation indicated that the level of impairment was most strongly related to land use and total flow of municipal 
wastewater effluent. Total flow of municipal wastewater effluent was positively related to the level of community impairment, indicating that drainage areas in New Jersey with high flows of municipal effluent are likely to have a severely impaired macroinvertebrate community. In both of these equations, the most significant variable was the total area of forested land upstream from the sampling site, which was significantly and positively related to the presence of an unimpaired macroinvertebrate community. All variables in these equations were statistically significant at the $p<0.001$ level. Additional significant logistic-regression equations relating the level of community impairment to alternative combinations of basin characteristics were evaluated; the two examples described herein, however, represent the overall best-fit equations.

\section{Summary and Discussion}

The comparison of macroinvertebrate community impairment in the Coastal Plain and New Jersey/New York Piedmont physiographic regions indicates no significant differences between the regions, but that these regions were more likely to exhibit impaired communities than were other regions (fig. 3). The presence of naturally depauperate communities in some streams with low bioassessment scores in the Coastal Plain may account for this finding; however, analysis by major drainage area, which separates the Coastal Plain into two sections (fig. 2), indicates that levels of impairment in the Atlantic Coastal Rivers drainage area, which contains most of New Jersey's Pinelands and large tracts of undeveloped and forested land, did differ significantly (contains fewer impaired sites) from those in the more urbanized Lower Delaware River drainage area (fig. 3). In addition, the Lower Delaware River drainage area did not differ significantly from the developed Passaic River drainage area (both have the greatest number of impaired sites), which drains a large part of the highly urban New Jersey/New York Piedmont (fig. 3).

The Reading Prong and Valley and Ridge physiographic regions are among the least urban and populated regions studied (table 1), and are least likely to exhibit an impaired macroinvertebrate community. The Valley and Ridge physiographic region is less intensively urbanized than the other physiographic regions because of its steep, mountainous terrain. In addition, all of the Valley and Ridge physiographic region falls within the boundaries of the Upper Delaware River

Table 3. Description of dependent variables (level of macroinvertebrate community impairment) and explanatory variables (basin characteristics) used in logistic-regression analysis

[Integers after variable names represent distance-weighed decay factors and indicate proximity of a source to a sampling site. For example, if the number is close to 1 (high decay factor), contributions from a source near a sampling site are most important, whereas if a number is close to 10 (low decay factor) sources in the entire basin upstream from a sampling site are important. $\mathrm{km}^{2}$, square kilometers; $\mathrm{ft}^{3} / \mathrm{s}$. cubic feet per second; EPT, Ephemeroptera (mayflies). Plecotera (stoneflies). Trichoptera (caddisflies); N. number of samples; SD, standard deviation; >, greater than; Min., minimum data value; Med., median data value; Max., maximum data value|

\section{Dependent variables}

\begin{tabular}{|c|c|c|c|c|}
\hline $\begin{array}{l}\text { Level of impairment } \\
\text { and range of scores }\end{array}$ & Variable code and description & $\mathrm{N}$ & Mean & $\mathrm{SD}$ \\
\hline $\begin{array}{l}\text { Non-impaired } \\
(24-30)\end{array}$ & $\begin{array}{l}1 \text { - Benthic macroinvertebrate community is comparable ( }>79 \%) \text { to } \\
\text { those in undisturbed streams and is characterized by high taxa } \\
\text { richness, high equitability, and many intolerant individuals. }\end{array}$ & 251 & 27.4 & 2.5 \\
\hline $\begin{array}{l}\text { Moderately impaired } \\
(9-21)\end{array}$ & $\begin{array}{l}2 \text { - Reduced macroinvertebrate richness and EPT abundance, low } \\
\text { equitability, and an absence of intolerant taxa. }\end{array}$ & 375 & 14.8 & 4.0 \\
\hline $\begin{array}{l}\text { Severely impaired } \\
(0-6)\end{array}$ & $\begin{array}{l}3 \text { - Community is dominated by a few highly abundant species and } \\
\text { tolerant taxa typically are the only individuals present. }\end{array}$ & 85 & 4.5 & 2.2 \\
\hline
\end{tabular}

Explanatory variables

\begin{tabular}{|l|l|c|c|c|}
\hline \multicolumn{1}{|c|}{ Variable name } & \multicolumn{1}{|c|}{ Description, unit of measurement, and source of data } & Min. & Med. & Max. \\
\hline FOR-3 & $\begin{array}{l}\text { Area of forested and undeveloped land }\left(\mathrm{km}^{2}\right) \text { aggregated upstream } \\
\text { (Fegeas and others, 1983). }\end{array}$ & 0 & 5.0 & 52.8 \\
URB-3 & $\begin{array}{l}\text { Area of Landsat Thematic Mapper data for August } 1985 \text { classified } \\
\text { as urban land }\left(\mathrm{km}^{2}\right) \text { aggregated upstream. }\end{array}$ & 0 & 3.6 & 100.4 \\
CP-3 & Area underlain by the Coastal Plain physiographic region $\left(\mathrm{km}^{2}\right)$. & 0 & 6.3 & 110.6 \\
RP-3 & Area underlain by the Reading Prong physiographic region $\left(\mathrm{km}^{2}\right)$. & 0 & 6.9 & 50.8 \\
PFM-5 & Total flow of municipal effluent $\left(\mathrm{ft}^{3} / \mathrm{s}\right)$ (Robinson and others, 1995) & 0 & 0 & 36.6 \\
\hline
\end{tabular}


drainage area (figs. 1 and 2), which has the highest percentage of forest land use (table 2) and is significantly different from the other four major drainage areas (fig. 3) in that it is least likely to exhibit an impaired community. The Lower Delaware River and the urbanized and highly populated Passaic River drainage areas do not differ significantly and are more likely to exhibit a impaired macroinvertebrate community than the other drainage areas. These assessments appear to indicate that drainage areas in which urban development is intensive are more likely to exhibit a high proportion of severely and moderately impaired macroinvertebrate communities than those that are less intensively developed. This type of development is representative of the highly urban corridor that extends from the northeastern to the southwestern boundary of New Jersey, and is noticeably displayed by the level of macroinvertebrate community impairment shown in figure 2 .

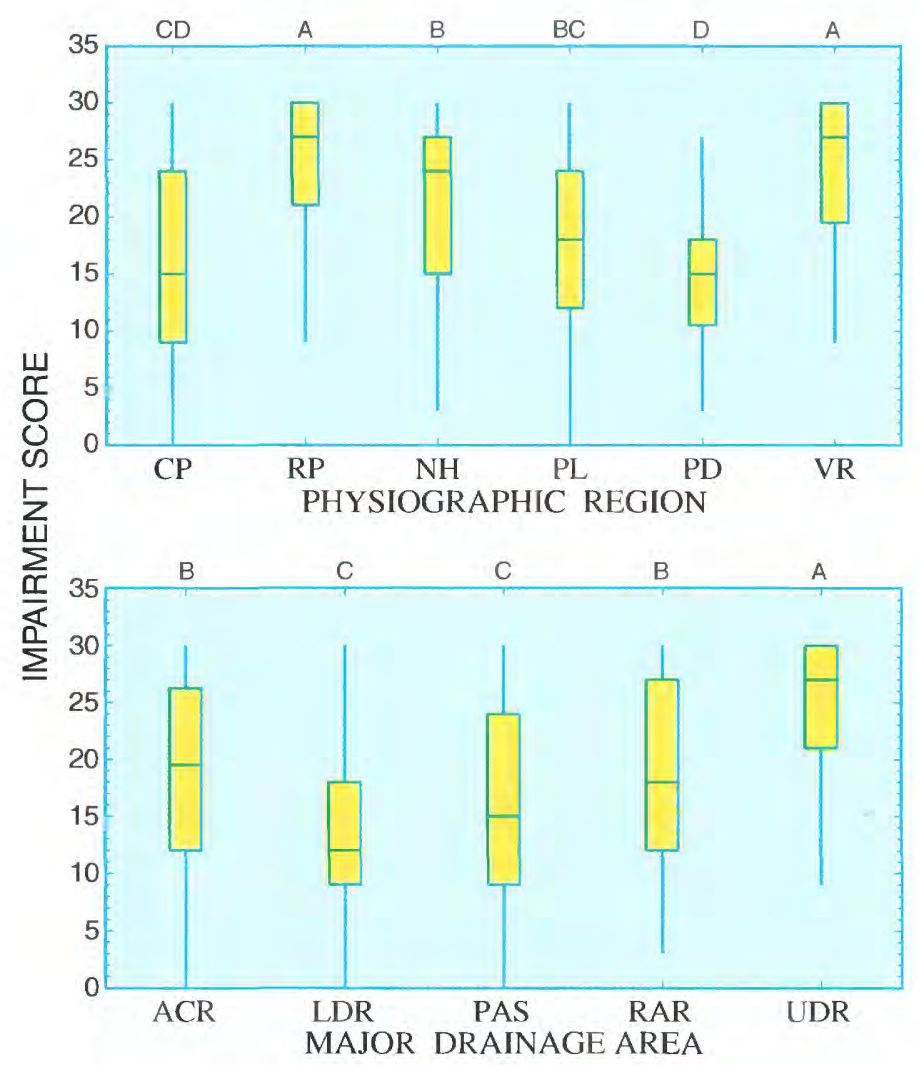

Figure 3. Statistical distributions of macroinvertebrate-communityimpairment scores and results of comparison tests (Tukey test) for physiographic regions and major drainage areas in New Jersey. [The letters A through D above each boxplot represent successively decreasing mean impairment scores. Major drainage areas or physiographic regions that have letters in common do not differ significantly with respect to level of impairment; for example, the mean level of community impairment in the Coastal Plain (assigned the letters $\mathrm{C}$ and D) is not statistically different from that in the New Jersey/New York Piedmont (assigned the letter D). CP. Coastal Plain; RP. Reading Prong; NH, New Jersey/New York Highlands; PL, Northern Piedmont Lowlands; PD, New Jersey/New York Piedmont; VR, Valley and Ridge; ACR, Atlantic Coastal Rivers; LDR, Lower Delaware River; PAS, Passaic River; RAR, Raritan River; UDR, Upper Delaware River; boxplot consists of a center line (median or 50th percentile) splitting a rectangle defined by the 25 th and 75 th percentiles; "whiskers" are lines drawn from the ends of the box to the maximum and minimum data points (Helsel and Hirsch, 1992)]
Results of the logistic-regression analysis confirm the strong association of upstream land use and basin characteristics with macroinvertebrate community condition in New Jersey streams. Generally, these analyses showed that severe community impairment is most significantly and positively related to the area of urban land and total flow of municipal effluent, and most significantly and negatively related to area of forested land and area underlain by the Reading Prong physiographic region. These findings are consistent with results of previous studies by Richards and Host (1994) and Richards and others (1996), who also found a significant relation between land-use characteristics and benthic macroinvertebrate community composition. These results also agree with those of Wright and others (1995), who found that benthic communities at sites that receive sewage effluent differed markedly in taxonomic richness from reference sites that do not.

Significant relations between urbanization and severe macroinvertebrate community impairment are particularly apparent in the best-fit logistic-regression equations. Many studies over the last two decades have indicated with remarkably consistent results that urban development can and does degrade benthic communities. Jones and Clark (1987) found that increasing urbanization was associated with an increase in tolerant taxa and a decrease in macroinvertebrate diversity. Garie and McIntosh (1986) found that benthic invertebrate richness, population density, and a shift in community composition were directly related to increasing urbanization. It is clear that increasing urbanization and consequent decreasing area of forested land greatly affect the biotic integrity of benthic communities.

Many of the factors linked to the degradation of benthic communities are becoming better understood. Factors such as the amount of impervious area (areas in a watershed covered by asphalt, concrete, buildings, and other compacted surfaces), urban runoff, increased suspended-sediment loads, poor habitat quality, sewage effluent, and increasing urbanization all have been shown to affect the hydrology, geomorphology, and water quality of stream systems. The results of this study support these findings and the approach outlined here appears to be an effective predictor of differences in level of benthic community impairment.

This fact sheet describes the relations between the level of benthic community impairment and basin characteristics at the drainage-area. physiographic-region, and state scale. Even at these relatively coarse scales. specific variables emerged as good predictors of macroinvertebrate community impairment. The area of forested land in a drainage area proved to be the best predictor of the presence of an unimpaired benthic community, whereas the area of urban land near a sampling site and total flow of municipal wastewater effluent were the best indicators of the presence of a severely impaired benthic community.

Ultimately, a more comprehensive understanding of the structure of benthic communities in New Jersey streams will be derived from additional analyses integrating surrounding landscape features at multiple spatial scales (stream-reach, stream-segment, and basinwide) and more detailed, site-specific water-quality assessments.

-Jonathan G. Kennen 


\section{References Cited}

Anderson, J.R., Hardy, E.E., Roach, J.T., and Witmer, R.E., 1976, A land use and land cover classification system for use with remote sensor data: U.S. Geological Survey Professional Paper 964, 28 p.

Cuffney, T.F., Gurtz, M.E., and Meador, M.R., 1993, Methods for collecting benthic invertebrate samples as part of the National Water-Quality Assessment Program: U.S. Geological Survey Open-File Report 93-406, 66 p.

Fegeas, R.G., Claire, R.W., Guptill, S.C., Anderson, K.E., and Hallam, C.A., 1983, Land use and land cover digital data: U.S. Geological Survey Circular 895-E, 21 p.

Garie, H.L., and McIntosh, Alan, 1986, Distribution of benthic macroinvertebrates in a stream exposed to urban runoff: Water Resources Bulletin, v. 22. p. 447-455.

Gilliom, R.J., Alley, W.M., and Gurtz, M.E., 1995, Design of the National Water-Quality Assessment Program: Occurrence and distribution of water-quality conditions: U.S. Geological Survey Circular 1112, 33 p.

Helsel, D.R., and Hirsch. R.M., 1992. Statistical methods in water resources: Studies in Environmental Science, no. 49. New York, Elsevier Publishers, Inc., 522 p.

Hosmer, D.W., and Lemeshow, Stanley, 1989, Applied logistic regression: New York, John Wiley and Sons, Inc., 307 p.

Jones, R.C., and Clark. C.C., 1987, Impact of watershed urbanization on stream insect communities: Water Resources Bulletin, v. 23, p. 1,047-1,055.

Karr, J.R., 1981, Assessment of biotic integrity using fish communities: Fisheries, v. 6, p. 21-27.

Lanfear, K.J., 1993, 1980 point population coverages for the conterminous United States, from U.S. Bureau of the Census, 1980 Master Area Reference File for 1980 Census (United States). [Arc/Info format data file available at U.S. Geological Survey, West Trenton, New Jersey].

New Jersey Department of Environmental Protection, 1994, The establishment of ecoregion biological reference sites for New Jersey streams: Trenton, N.J., New Jersey Department of Environmental Protection, Bureau of Water Monitoring, $17 \mathrm{p}$.

Plafkin, J.L., Barbour, M.T., Porter, K.D., Gross, S.K., and Hughes, R.M., 1989, Rapid bioassessment protocols for use in streams and rivers: Benthic macroinvertebrates and fish: U.S. Environmental Protection Agency, EPA/444/4-89/001.

Reynoldson, T.B., Norris, R.H., Resh, V.H., Dey, K.E., and Rosenberg, D.M., 1997, The reference condition: A comparison of multimetric and multivariate approaches to assess water-quality impairment using benthic macroinvertebrates: Journal of the North American Benthological Society, v. 16, no. 4, p. 833-852.

Richards, Carl, and Host, G.E., 1994, Examining land influences on stream habitats and macroinvertebrates: A GIS approach: Water Resources Bulletin, v. 30, p. 729-738.

Richards, Carl. Johnson. J.D.. and Erickson, D.L., 1996. Landscape-scale influences on stream habitats and biota: Canadian Journal of Fisheries and Aquatic Sciences, v. 53, p. 295-311.
Robinson, K.W., Price, C.V., and Smith, R.A., 1995,

Development of a computerized data base of permitted wastewater discharges in New Jersey: U.S. Geological Survey Open-File Report 95-152, 14 p.

U.S. Bureau of the Census, 1991, Census of population and housing, 1990: Public Law 94-171 data for New Jersey: Washington, D.C., U.S. Bureau of the Census [machinereadable data files (CD-ROM)].

White, D.A., Smith, R.A., Price, C.V., Alexander, R.B., and Robinson, K.W., 1992, A spatial model to aggregate pointsource and nonpoint-source water-quality data for large areas: Computers and Geosciences, v. 18, no. 8 , p. 1,055-1.073.

Wright, I.A., Chessman, B.C., Fairweather, P.G., and Benson, L.J., 1995, Measuring the impact of sewage effluent on the macroinvertebrate community of an upland stream: The effect of different levels of taxonomic resolution and quantification: Australian Journal of Ecology, v. 20, p. $142-149$.

Zar, J.H., 1984, Biostatistical analysis (2d ed.): Englewood Cliffs, New Jersey, Prentice-Hall, Inc., 718 p.

\section{Acknowledgments}

The author thanks the many individuals from the New Jersey Department of Environmental Protection, Bureau of Water Monitoring, who collected the invertebrate samples and checked the data used in the analysis. especially Paul Olsen, John and Barbara Kurtz, Thomas Miller, Dean Bryson, Charles Lawless, and Victor Poretti. Thoughtful reviews and comments were provided by Alfred Korndoerfer of the NJDEP and Stephen Sorenson and Dale Simmons of the USGS.

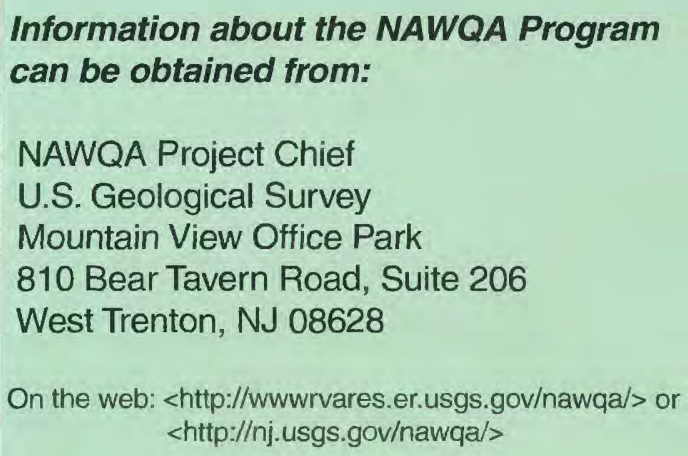

Information about the NJDEP Ambient Biomonitoring Network (AMNET) can be obtained from:

Administrator, Water Monitoring Management NJDEP- Division of Science and Research CN409

Trenton, NJ 08625

On the web: <http://www.state.nj.us/dep/dsr/> 